University of South Florida

DIGITAL COMMONS

@ UNIVERSITY OF SOUTH FLORIDA
Digital Commons @ University of

South Florida

7-1-2001

\title{
Where are the Future Transit Maintenance Technicians Coming From?
}

CUTR

Follow this and additional works at: https://digitalcommons.usf.edu/cutr_nctr

\section{Scholar Commons Citation}

CUTR, "Where are the Future Transit Maintenance Technicians Coming From?" (2001). Research Reports. 199.

https://digitalcommons.usf.edu/cutr_nctr/199

This Technical Report is brought to you for free and open access by the National Center for Transit Research (NCTR) Archive (2000-2020) at Digital Commons @ University of South Florida. It has been accepted for inclusion in Research Reports by an authorized administrator of Digital Commons @ University of South Florida. For more information, please contact digitalcommons@usf.edu. 


\section{WHERE ARE THE FUTURE TRANSIT MAINTENANCE TECHNICIANS COMING FROM?}




\section{Table of Contents}

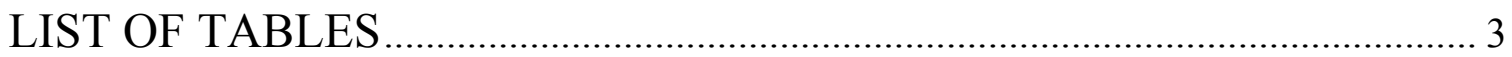

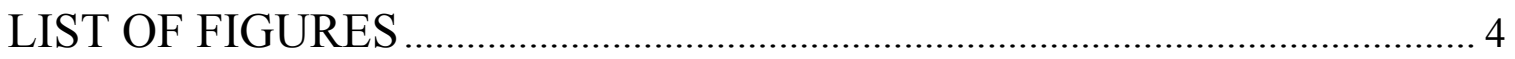

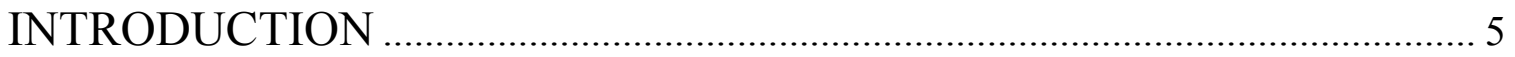

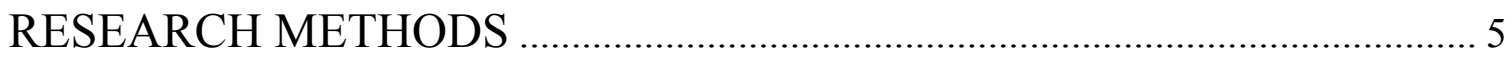

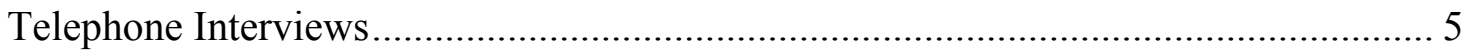

National Transit Maintenance Technician Recruitment and Retention Survey.............. 6

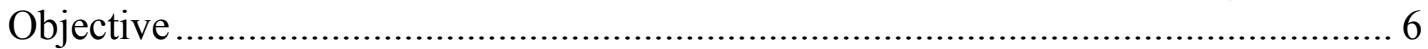

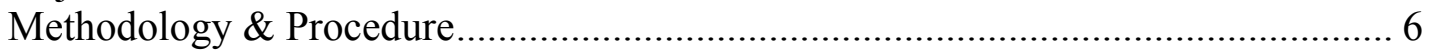

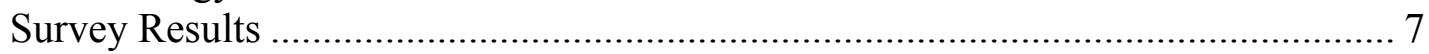

CHARACTERISTICS OF THE WORKFORCE ……………………............. 9

An Aging Workforce ……………………………….......................................... 9

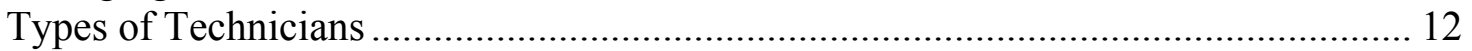

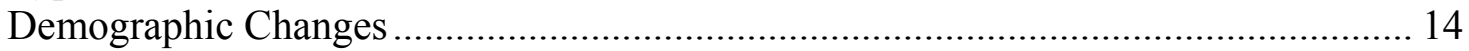

ISSUES AFFECTING EMPLOYMENT_................................................... 14

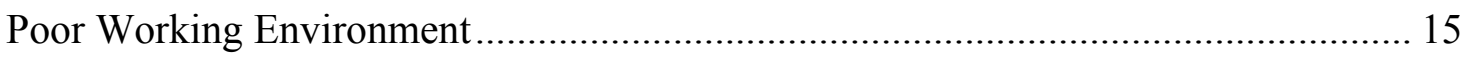

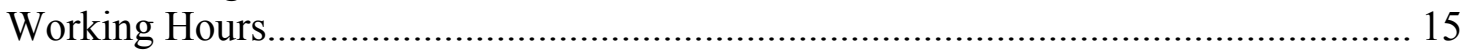

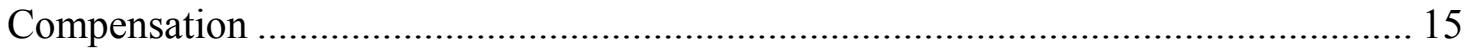

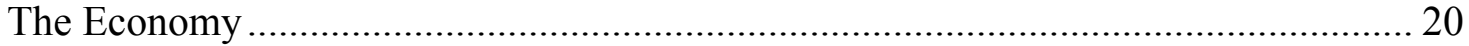

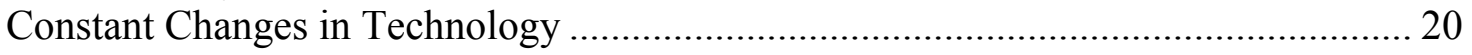

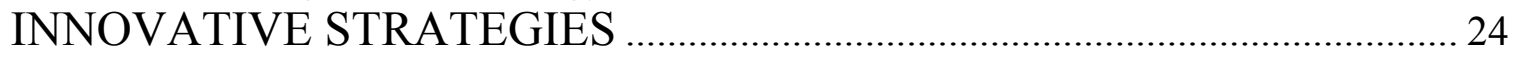

Continuing Education and Professional Development ………………….................... 24

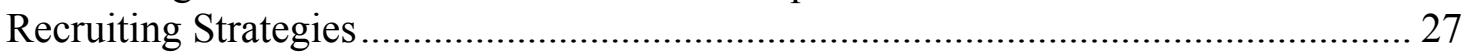

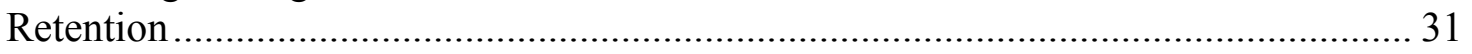

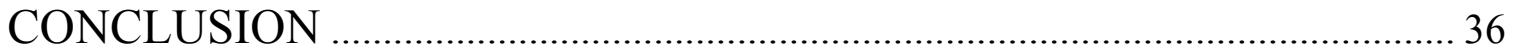

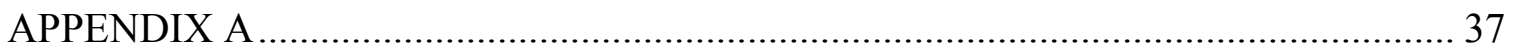

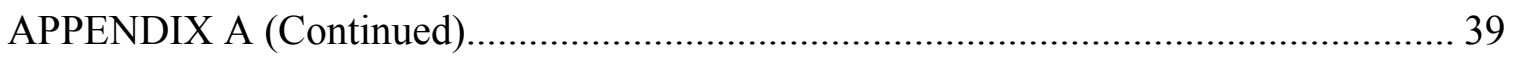

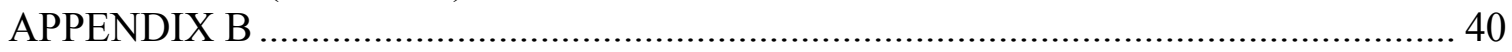

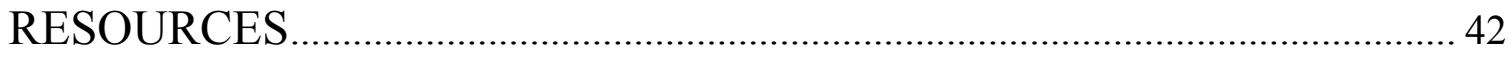




\section{LIST OF TABLES}

Table 1-1 Response Rate By Question............................. 8

Table 1-2 U.S. Population Aged 25 and Older By Age, 2000, 2010.... 10

Table 1-3 Occupations With the Greatest Percentage of Workers Aged 45 and Older Permanently Leaving the Occupation, 1998-2000... 12

Table 1-4 Hourly Pay Rate....................................... 17

Table 1.5 Training and Professional Development Opportunities......... 23

Table 1-6 Recruitment Techniques.............................. 30

Table 1-7 Opportunities for Overtime............................. 34

Table 1-8 Techniques For Retaining Technicians.................... 35 


\section{LIST OF FIGURES}

Figure 1-1 Age of Technicians...................................... 11

Figure 1-2 Number of Diesel and Automotive Mechanics................ 13

Figure 1-3 Technicians Pay Per Hour................................ 17

Figure 1-4 Technician Belonging to Unions........................... 18

Figure 1.5 Percentage of HS Graduates Enrolling In College 1993-1998.. 21

Figure 1-6 Length of Employment.................................. 31 


\section{INTRODUCTION}

Under contract with the Florida Department of Transportation (FDOT), the Center for Urban Transportation Research (CUTR) was asked to research and assess the future of the transit maintenance technician workforce. The main scope of this project focuses on this question: "Where are the future transit maintenance technicians coming from?" Will transit agencies be able to attract and retain the number of technicians necessary to maintain their vehicles in the coming years? Unfortunately, these questions do not have a simple answer. There are many factors that contribute to the ongoing dilemma of recruiting and keeping transit maintenance technicians.

\section{RESEARCH METHODS}

This report identifies and addresses many of the key factors that affect the transit maintenance technicians of today and the issues that affect their employment. Researchers assigned to this project used information and research from census data and the Bureau of Labor Statistics (BLS). Additionally, telephone interviews were performed throughout the scope of this project to obtain additional information from public transit

maintenance managers. Lastly, a survey instrument was created, distributed and analyzed by CUTR staff to obtain additional demographic information.

\section{Telephone Interviews}

Several transit agencies were selected at random and contacted via telephone for interviews. Additional phone interviewees were selected based on research discovered. 


\title{
National Transit Maintenance Technician Recruitment and Retention Survey
}

\author{
Objective
}

The National Transit Maintenance Technician Recruitment and Retention Survey was undertaken in order to achieve a number of specific objectives. The main objectives of the survey were to:

- collect data nationally that would be useful in determining the size of the current transit maintenance technician population;

- identify demographic characteristics of transit maintenance technicians;

- understand issues that affect transit maintenance technicians; and

- gather relevant information necessary to understand and analyze the health of the industry

\section{Methodology \& Procedure}

A questionnaire, developed by the Center for Urban Transportation Research (CUTR) asked 13 questions that would allow for the collection of descriptive information regarding demographic characteristics of transit agencies. Additionally, specific questions were asked about the retention and recruitment procedures and programs offered by transit agencies nationwide.

CUTR used a graduate assistant to receive, cumulate, and enter the data received from the returned surveys. The 2001 American Public Transportation Associate (APTA) directory was used to locate addresses for transit agencies. None of the agencies received advance notice that they would be surveyed. Agencies were sent a survey with a self-addressed 
stamped envelope via U.S. Mail. Included with the survey were two return options.

Respondents were offered a mail-back option with a self-addressed, stamped, envelope or it could be returned via facsimile. The survey was also posted on the Florida Department of Transportation/CUTR's Maintenance Forum Listserv. Surveys were printed in English only.

\section{$\underline{\text { Survey Results }}$}

The results of the survey are analyzed throughout this report. The majority of questions on the survey were open-ended in nature, requiring respondents to write in their response. Attachment A is a copy of the survey that was distributed to Human Resource Managers, Maintenance Managers, Directors, and General Managers. The overall response rate was $21.3 \%$, which is average for this type of survey. The responses to each question are summarized and analyzed below.

Table 1-1 presents response rates by question. Questions 1 and 10 received the largest response rate of $100 \%$. The overall response rate was good with the exception of Questions 5 (79\%) and $8(82 \%)$. 
Table 1-1

Response Rate By Question

\begin{tabular}{|c|l|c|}
\hline Question \# & \multicolumn{1}{|c|}{ Question } & Response Rate \\
\hline Question 1 & What is the name and address of your agency? & $100 \%$ \\
\hline Question 2 & How many technicians do you employ? & $98 \%$ \\
\hline Question 3 & $\begin{array}{l}\text { How many technicians fall into the following age } \\
\text { ranges: 18-24, 25-34, 35-44, 45-64, 65 or older? }\end{array}$ & $95 \%$ \\
\hline Question 4 & $\begin{array}{l}\text { How many of those will be retiring from their } \\
\text { positions within the next: five years/ten years? }\end{array}$ & $92 \%$ \\
\hline Question 5 & $\begin{array}{l}\text { Please list any opportunities for supplemental pay } \\
\text { through overtime work. }\end{array}$ & $79 \%$ \\
\hline Question 6 & How many of your technicians are ASE certified? & $89 \%$ \\
\hline Question 7 & $\begin{array}{l}\text { How many of your technicians have completed } \\
\text { formal trade school training? }\end{array}$ & $82 \%$ \\
\hline Question 8 & $\begin{array}{l}\text { What is the average length of employment for a } \\
\text { technician at your agency? }\end{array}$ & $92 \%$ \\
\hline Question 9 & How much do your technicians get paid per hour? & $90 \%$ \\
\hline Question 10 & $\begin{array}{l}\text { What additional training and professional } \\
\text { development opportunities does your agency offer? }\end{array}$ & $100 \%$ \\
\hline Question 11 & How do you recruit technicians? & $98 \%$ \\
\hline Question 12 & $\begin{array}{l}\text { How do you retain your technicians? Pay well, } \\
\text { incentive programs, etc. }\end{array}$ & $93 \%$ \\
\hline Question 13 & How many of your technicians belong to a union? & $96 \%$ \\
\hline
\end{tabular}




\section{CHARACTERISTICS OF THE WORKFORCE}

It is critical to look at the nation as a whole, in order to determine the status of today's workforce. Once we examine the general workforce, we can then begin to identify key issues and concerns that will affect public transit technicians. This section will identify demographic and technological shifts in the maintenance technician field. There are many characteristics of the workforce that affect the ability to retain and replace employees. Agencies need to understand the changing characteristics of the overall workforce in order to identify those changes that may directly impact the public transit maintenance fields.

\section{An Aging Workforce}

We are starting to see, and will continue to see, an increase in the number of people retiring due to baby boomers entering the age of retirement and a thriving economy which allows them the flexibility of early retirement. The era of the baby boomers began in 1946 and continued through 1964. During those years, nearly 76 million people were born. As the oldest of the baby boomers enter into the age of retirement in the next several years, their departure from the workforce will cause a sudden and definite impact. The movement of baby boomers into retirement will affect many professions, including that of the public and private sector maintenance technician. There will be a larger number of jobs available than people to fill the positions. It is critical for transit agencies to understand and prepare for this phenomenon.

Table 1-2, allows us to understand the overall US population by age demographic. Table 1-2, U.S. Population Aged 25 and Older By Age, 2000 and 2010, shows the population distribution by age. The 55 to 64 age cohort shows a significant increase of more than 47 percent between 2000 and 2010. In addition, while the number of people aged 25-64 is 
expected to increase by about 12.8 million over a ten year period, almost 90 percent of this increase is projected to occur among persons aged 55 to 64 .

Based on the data represented in Table 1-2, there will be a significantly higher number of individuals entering into retirement age in the near future. The true results of this change in age demographic and how it will affect the employment of our population is unknown.

Table 1-2

U.S. Population Aged 25 and Older By Age, 2000 \& 2010 [Numbers in thousand]

\begin{tabular}{|l|c|c|c|c|}
\hline \multicolumn{1}{|c|}{ Age $\boldsymbol{\&}$ Sex } & $\mathbf{2 0 0 0}$ & $\mathbf{2 0 1 0}$ & Level Change & \% Change \\
\hline 25 to 34 years & 37,234 & 38,291 & 1,057 & 2.8 \\
\hline 35 to 44 years & 44,659 & 38,520 & $-6,139$ & -13.7 \\
\hline 45 to 54 years & 37,030 & 43,565 & 6,535 & 17.6 \\
\hline 55 to 64 years & 23,962 & 35,284 & 11,322 & 47.2 \\
\hline 65 years $>$ & 34,709 & 39,407 & 4,698 & 13.5 \\
\hline
\end{tabular}

Source: Jennifer Cheeseman Day, Population Projections of the United States by Age, Sex, Race and Hispanic Origin: 1995 to 2050, Current Population Reports, Series P-25-1130 (Bureau of the Census, 1996)

To narrow down the age demographic to just transit maintenance technicians, CUTR included an age distribution question in their national survey. According to survey results analyzed by CUTR the majority (51\%) of today's technicians are age 45 and older. This indicates that a large percentage of people within this industry will be entering into the age of retirement within the next 10-15 years.

Figure 1-1 graphically distributes technicians by age according to the survey results. These results correlate with the research that the Department of Labor has completed. Those technicians born at the beginning half of the baby booming years are 55 and younger and represent $51 \%$ of the respondents. Those born in the later half of the baby booming years are 37 (35-44) and younger, representing 38\%. Only 18\% fall into the 2534 age range category and only $3 \%$ are in the $18-24$ category. 
Figure 1-1

Age of Technicians

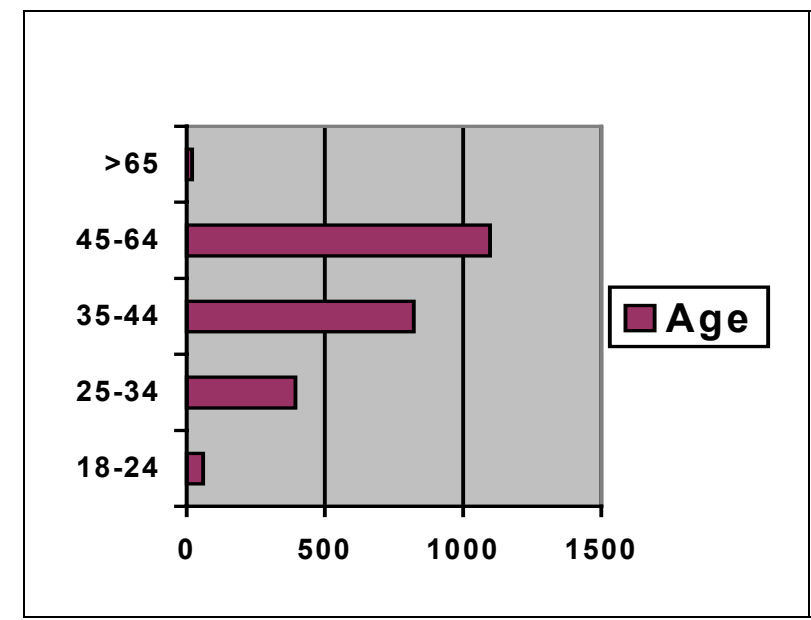

Source: National Transit Maintenance Technician Recruitment and Retention Survey, 2001, Center for Urban Transportation Research, University of South Florida.

Because actual retirement age can vary from person to person, it was important to ask agencies, how many of their technicians would retire within the next 5-10 years. Approximately, 12\% percent of the technicians will be retiring in 5 years and almost 27\% in 10 years. In total, $39 \%$ of the technicians represented in this survey will be retiring within the next 10 years.

In a report prepared by Arlene Dohm entitled, "Gauging the Labor Force Effects of Retiring Baby Boomers", occupations were identified that will have the most need for employee replacement due to persons retiring. The job of the mechanic/repairer/supervisor was among the top seven. Table 1-3, Occupations With the Greatest Percentage of Workers Aged 45 and Older Permanently Leaving the Occupation, 1998-2008 represents the findings of the study. These jobs were chosen due to the combination of both a larger percentage of persons over the age of 45 and the occupations having employees that are generally older than average. It is this combination which make these occupations stand out. The table shows that 68.3 percent of supervisors, mechanics \& repairers aged 45 and older will permanently leave their 
occupation between 1998-2008. This percentage is significantly higher than the total of all employees permanently leaving their occupations during the same time period ( 53.8 percent).

Table 1-3

Occupations With the Greatest Percentage of Workers Aged 45 and Older Permanently Leaving the Occupation, 1998-2008

\begin{tabular}{|c|c|}
\hline Occupation & $\begin{array}{c}\text { Workers permanently leaving the } \\
\text { occupation (\%) }\end{array}$ \\
\hline Total, all employees & 53.8 \\
\hline Fishers, hunters and trappers & 80.5 \\
\hline Water Trans. Occupations & 76.7 \\
\hline Operations \&system researchers & 74.2 \\
\hline Supervisors, police, detectives & 70.9 \\
\hline Telephone Installers \& Repairs & 69.6 \\
\hline Insurance underwriters & 68.6 \\
\hline Supervisors, mechanics \& repairers & 68.3 \\
\hline
\end{tabular}

Source: Dohm, Arlene. "Gauging the Labor Force Effects of Retiring Baby Boomers."

\section{Types of Technicians}

There are many different types of mechanics and technicians. It is important to identify the number of individuals in each category in order to properly identify their issues and outside influences.

Diesel mechanics and service technicians held approximately 255,000 jobs in 1998 (Figure 1-2). About 20 percent of them worked to maintain the buses and trucks for bus lines, public transit companies, and school systems, and federal, state and local governments. Approximately 25 percent serviced trucks and other diesel-powered 
equipment for vendors, dealers, leasing companies and independent automotive repair shops.

Automotive mechanics and service technicians held about 790,000 jobs in 1998, which is significantly more than the jobs held by diesel mechanics (Figure 1-2). The majority of automotive technicians worked for retail and wholesale auto dealers, independent automotive repair shops, or gasoline service stations. A small number maintained fleets for taxicab and automobile leasing companies, federal, state and local governments, and other organizations. ${ }^{1}$

Figure 1-2

Number of Diesel and Automotive Mechanics

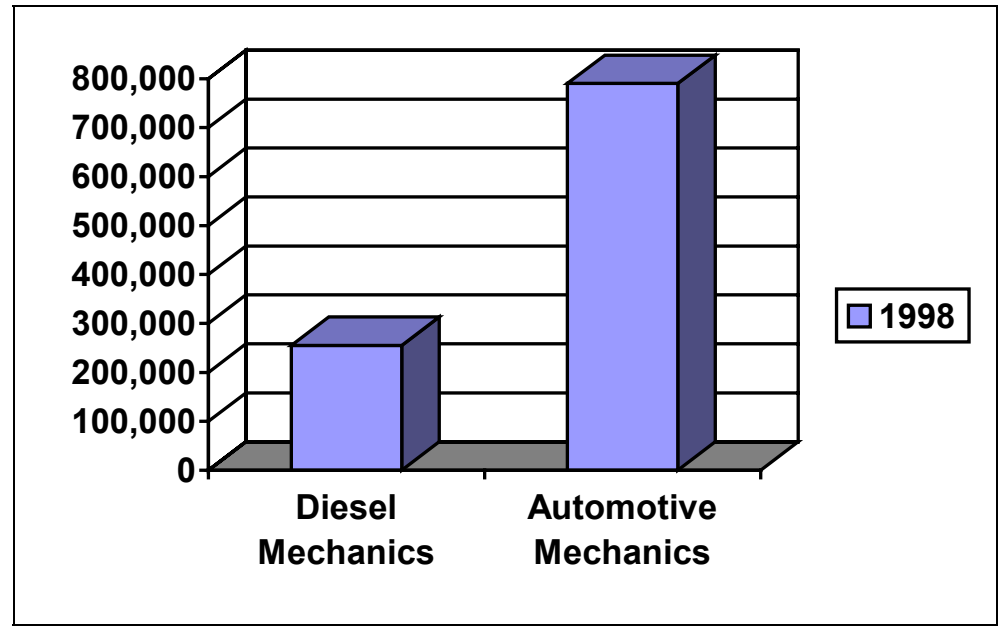

Source: Department of Labor Occupational Outlook Handbook, US Department of Labor, Bureau of Labor Statistics, 2000.

While the industry overall can expect a large age demographic shift in the next several years, the Department of Labor estimates that employment of diesel mechanics and service technicians will increase parallel (linearly) with the average occupation through 2008. However, after 1998 we can expect to see the number of retiring technicians

\footnotetext{
${ }^{1}$ Occupational Outlook Handbook, US Department of Labor, Bureau of Labor Statistics. 2000.
} 
increasing significantly. With the onset of the baby boomers retiring, we will see a large number of employers fiercely recruiting for potential job candidates. Transit agencies will have to have incentives in place or be prepared to pay higher salaries in order to recruit new technicians.

\section{Demographic Changes}

In addition to a significantly low unemployment rate, the overall employment demographic picture is rapidly changing. In the near future, we will see an increased growth rate in the number of youths entering the workforce with new skills and education. In addition to the age disparity in the new workforce, the American workforce will have a new racial demographic profile. The percentage distribution by race has shifted and will continue to change. By 2050, minorities are projected to rise from one in every four Americans to almost one in every two. ${ }^{2}$

Demographic profiles are very important. Maintenance employers need to know who their potential employers may be and offer them jobs with benefits that suit their needs and lifestyles. This is a critical concept when employers want to create retention and recruitment programs.

\section{ISSUES AFFECTING EMPLOYMENT}

There are many issues which affect the employment of a maintenance technician. Both public and private sector maintenance technicians identify with similar key issues that affect their employment. Generally, there are several variables which adversely affect the maintenance technician industry. These variables range concerns with the working environment to compensation issues.

\footnotetext{
2 Jennifer Cheeseman Day, Population Projections of the United States by Age, Sex, Race and Hispanic Origin: 1995 to 2050, Current Population Reports (Bureau of the Census, 1996)
} 


\section{Poor Working Environment}

Throughout the United States transit maintenance facilities are large open structures with bays and high ceilings. Because of their size, they are typically not equipped or poorly equipped with central air conditioning and heating units. This makes it very difficult for technicians to work comfortably in their work environment because temperatures may be extreme. Adding to the effect of no or poorly working heating and cooling systems, some shops have garage bay doors which do not close. Consequently, maintenance technicians are exposed to natural elements including rain, sleet, hale, and snow as well as extreme heat and cold.

\section{Working Hours}

Since the transit maintenance technician job is a service industry position, work hours tend to be longer than that of the non-service sector. Many agencies operate seven days a week, 24 hours a day. Technicians are typically faced with extended workdays as well as extended workweeks. In some cases the workload exceeds the available workforce.

\section{Compensation}

Compensation is an ongoing issue. Some public and private sector agencies try to compensate for non-competitive wages, by offering "good" benefit packages including attractive retirement plans. It is critical for transit agencies to identify their technician's needs before offering compensation options which may not meet their employees lifestyle priorities.

Question 9 of the National Transit Maintenance Technicians Recruitment and Retention Survey asked respondents how much their technicians are paid per hour. This question is of particular interest because it is such an ongoing source of contention. Figure 1-3 
graphically illustrates the span and median pay by state. Table 1-4 specifies the average pay by state. The five states which have the highest paying rates per hour are California, Arizona, Hawaii, Wisconsin, and Washington. The five states whose rates per hour are the lowest include North Carolina, Pennsylvania, Montana, Florida, and Texas.

While compensation is typically relative to geographic location, most agencies pay technicians according to the local average costs of living. However, it is important to show the dramatic pay scale ranges from state to state. It is clear that states who have unionized technicians typically pay higher wages than those states whose technicians do not belong to unions (Figure 1-4). 
Figure 1-3

Technician Pay Per Hour

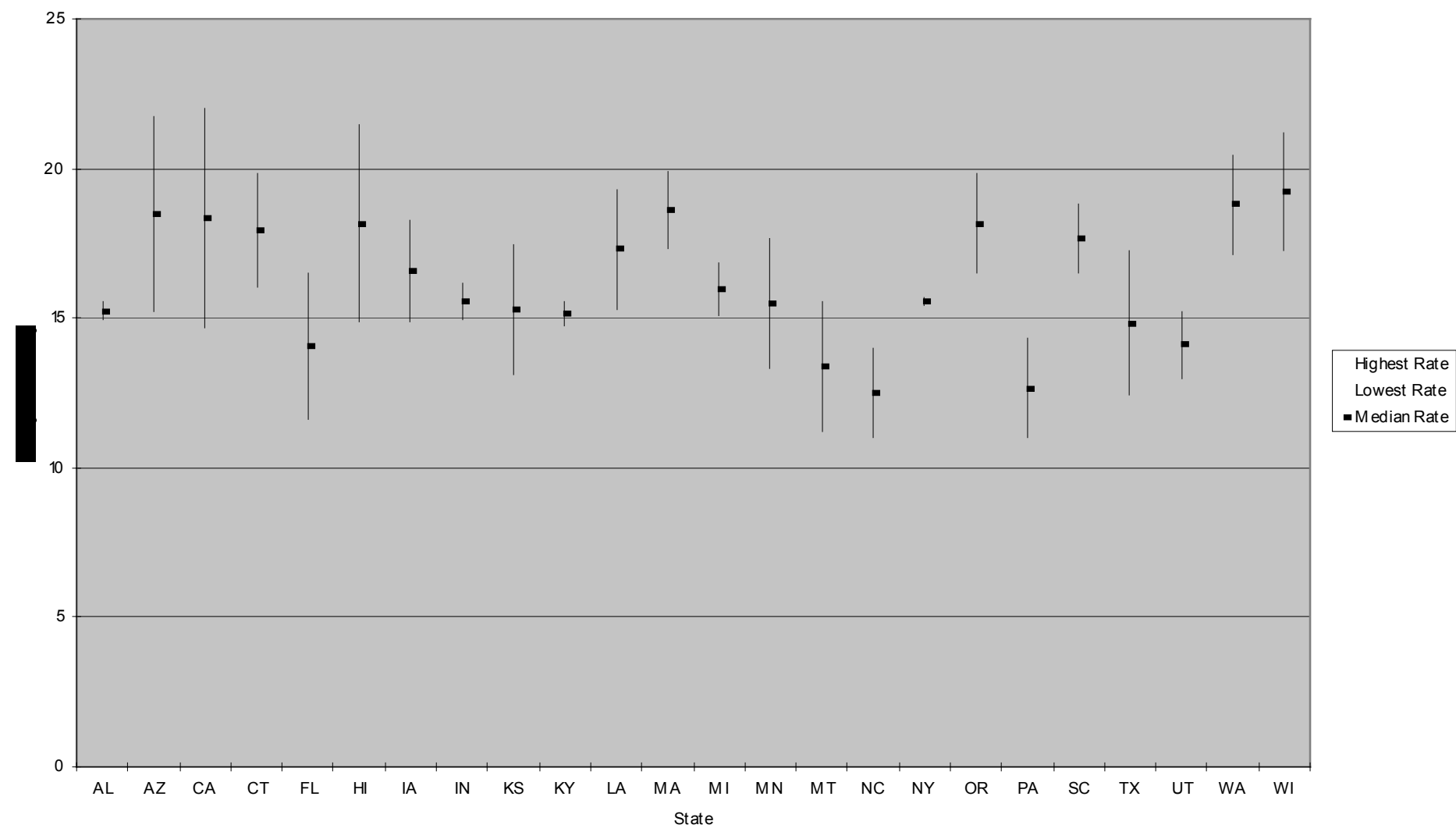


Figure 1-4

Technicians in Unions

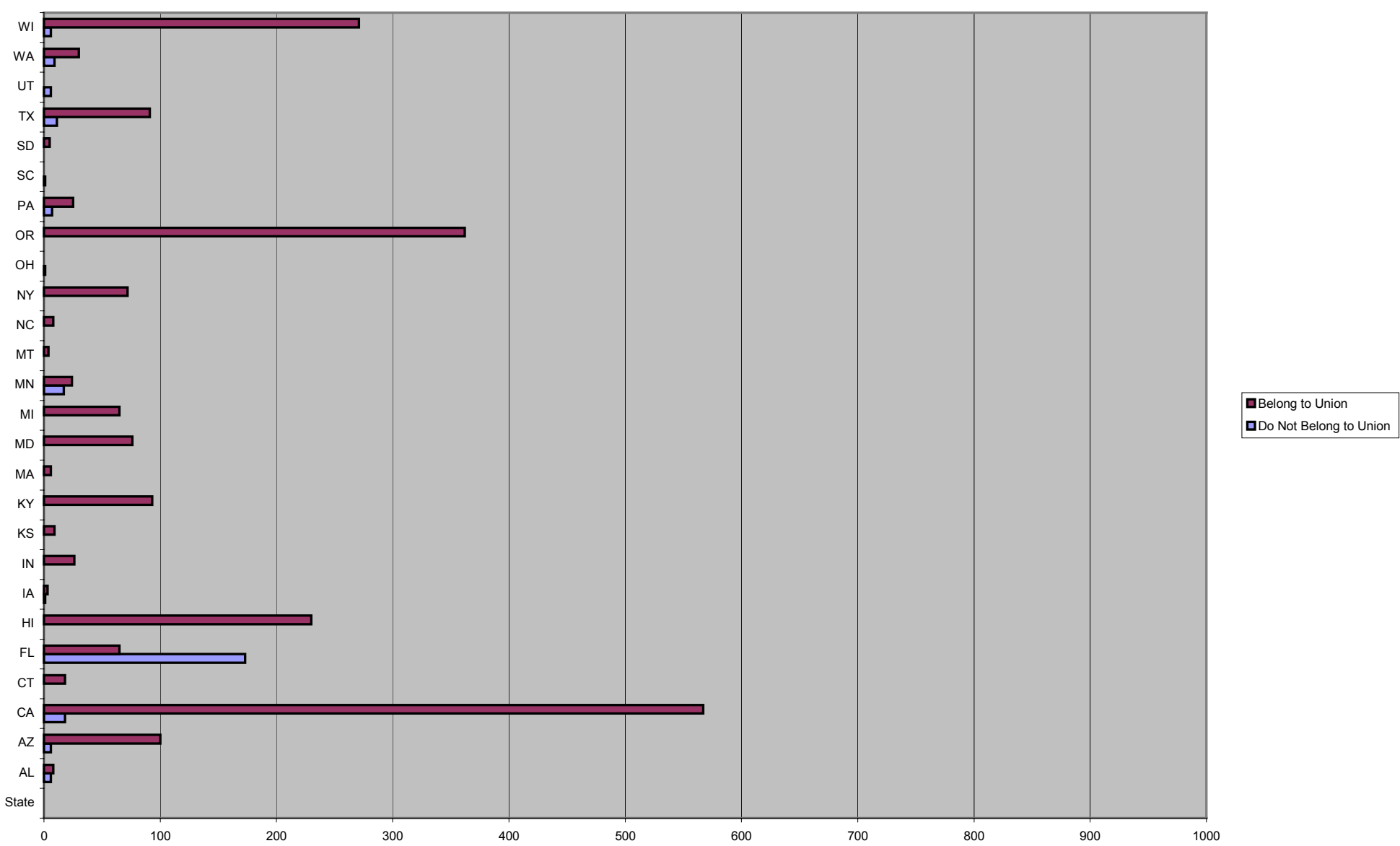


Table 1-4

Hourly Pay Rate

\begin{tabular}{|c|c|}
\hline State & Average Salary (Per/Hr) \\
\hline $\mathrm{AL}$ & $\$ 15.23$ \\
\hline$A Z$ & $\$ 18.45$ \\
\hline $\mathrm{CA}$ & $\$ 18.36$ \\
\hline CT & $\$ 17.95$ \\
\hline $\mathrm{FL}$ & $\$ 14.04$ \\
\hline $\mathrm{HI}$ & $\$ 18.17$ \\
\hline IA & $\$ 16.60$ \\
\hline IN & $\$ 15.55$ \\
\hline $\mathrm{KS}$ & $\$ 15.31$ \\
\hline $\mathrm{KY}$ & $\$ 15.14$ \\
\hline LA & $\$ 17.29$ \\
\hline MA & $\$ 18.62$ \\
\hline $\mathrm{MI}$ & $\$ 15.97$ \\
\hline $\mathrm{MN}$ & $\$ 15.47$ \\
\hline MT & $\$ 13.39$ \\
\hline $\mathrm{NC}$ & $\$ 12.50$ \\
\hline NY & $\$ 15.55$ \\
\hline OR & $\$ 18.14$ \\
\hline PA & $\$ 12.65$ \\
\hline SC & $\$ 17.65$ \\
\hline $\mathrm{TX}$ & $\$ 14.84$ \\
\hline UT & $\$ 14.10$ \\
\hline WA & $\$ 18.80$ \\
\hline WI & $\$ 19.23$ \\
\hline
\end{tabular}

Source: National Transit Maintenance Technicians Recruitment and Retention Survey, 2001. Center for Urban Transportation Research, University of South Florida, Tampa, Florida 


\section{The Economy}

One factor that directly affects the recruitment and retention of transit maintenance technicians is the economy. The economy of the United States and other foreign countries is one of the most significant outside influences to the job market. The state of the economy contributes to almost every factor of our lives. As the economy shifts, so does our way of life. If the economy is doing well we see a decrease in unemployment and an increase in retirement. The U.S. economy has shown an upward trend for the last several years. Employment experienced unprecedented growth during the late 1990s. As a result of this growth, the unemployment rate during this time fell to as low as 4.2 percent, the lowest in 29 years. This strong growth rate will continue into the next decade, according to the projections by the Department of Labor's Bureau of Labor Statistics (BLS). This employment growth will affect every industry.

The upward movement of the economy has made it difficult for public and private maintenance departments to fill jobs and keep them filled. Today's employment market is flooded with new job opportunities. The increase in job availability has now given employees more leverage over their employers. Employers are fighting to hold on to their existing employees and fiercely negotiating to hire new employees. This trend is evident in the public transit technician field. Technicians are being lured away by private organizations with the promise of better salaries, signing bonuses, more comprehensive benefits and potentially more flexible work hours.

\section{Constant Changes in Technology}

The technology revolution has changed the way the world, as a whole, does business. Technological advancement in equipment and communication are perhaps the greatest precipitating factor affecting the workforce. Technology has found its way into every job. Even jobs once considered non-technical have not been left out of the revolution. According to the BLS, "old school" mechanics will have tremendous difficulty finding 
employment if they lack the skills to use computer-based diagnostic equipment, which is now a standard in the industry.

Traditionally, those workers who repair, inspect, maintain and repair automobiles and light trucks with gasoline engines were called "mechanics." However, with the increasing sophistication of automotive technology, workers are now required to use computerized shop equipment and work with electronic components, while still maintaining their skills with traditional hand-held tools. Workers who possess these new skills are increasingly called "service technicians." 3

Technology is changing rapidly and technicians need the proper tools to do their job correctly. Every year there are new models of cars, trucks and buses being manufactured. Some manufactures have simple changes from year to year, while others completely change a model and all of its mechanical components. Technicians are expected to keep up-to-date with changing models, and the even more rapidly changing technologies.

What are the technological advances that transit technicians face? Multiplex instead of analog wiring systems; electronically controlled engines and sub-systems instead of mechanically controlled engines and sub-systems; electronically controlled A/C systems; anti-lock brakes; on- board electronics; complex revenue collection devices; talking buses with Global Positioning Systems (GPS) / Advanced Vehicle Location (AVL) interfaces; on board displays capable of sending and receiving messages; manifests delivered in real time; and digital camera systems that record on a hard drive capable of transmitting with a cellular signal when needed.

These technologies have forced technicians to be skilled in many facets. Although Maintenance Management from one industry to the other is a transferable skill, technical competency on automotive equipment is not as homogenized. The logistics of putting the right train, plane, automobile or bus into service at the right time, place and at the right quantity and cost is essentially the same. But the technical skill required to analyze and

\footnotetext{
${ }^{3}$ Occupational Outlook Handbook, US Department of Labor, Bureau of Labor Statistics. 2000.
} 
diagnose advanced systems on transit specific equipment needs to be taught.

Additionally, these transit specific skills become perishable through technology and nonuse.

With the introduction of Multiplex instead of analog wiring systems, the "old school" troubleshooting techniques on hundreds of yards of electrical wiring are slowly becoming extinct. Digital signals that lend themselves to electronically controlled engines and subsystems are becoming the norm. Air conditioning principals of operation change little, but it is the electronically controlled brains of the system that will require technicians to seek out new training. Anti-lock brakes have now made their way into transit, as well as complex revenue collection devices and on-board terminals capable of sending and receiving manifests and messages in real time. Digital camera systems that record data on a hard drive, capable of transmitting with a cellular signal, have also come of age. Concurrently, over the last four years, the use of computer-based vehicle tracking systems has increased exponentially. Their popularity in the U.S. has increased more than 200 percent. The information this technology transmits is undeniably valuable and is a major contributing factor to the ever-increasing positive image of transit as a whole. But who is going to maintain it? Where are these technicians going to come from?

Although the public transit industry has been slow to adopt the latest technological advances, as opposed to the private sector, the gap seems to be closing. In 1995, the American Public Transportation Association (APTA) assembled some of the industry's top leaders to work on a task force entitled Mobility for the $21^{\text {st }}$ Century (M21). Strategic goals and actions were developed based on what would be a sustainable future in transportation and related systems. One of the goals of the preferred future, as defined by the task force, was to invest in innovative technologies. This included speeding up the development of everything from alternative propulsion systems to smart card technology. This level of commitment, working to ensure that Intelligent Transportation Systems (ITS) remain at the forefront of research and development, virtually mandates that tomorrow's technician will have to be more than just a "mechanic." Certain task force 
initiatives have hastened the implementation of technology that is currently being seen in the garage.

\section{Education}

Today's workforce is very competitive. Education can serve to acquire better jobs, more money and more complete benefits. According to the BLS, nearly 83 percent of all adults ages 25 and over have completed high school, and 24 percent have obtained a bachelors degree or higher. This is in sharp contrast to 30 years ago, when less than 54 percent of adults completed high school, and less than 10 percent finished college. Not only are there a large number of Americans graduating from high school, but there is a large increase in the number attending college. In 1996, 66 percent of high school graduates entered colleges and universities (Figure 1-5).

Figure 1-5

\section{Percentage of High School Graduates Enrolling In College 1993-1998}

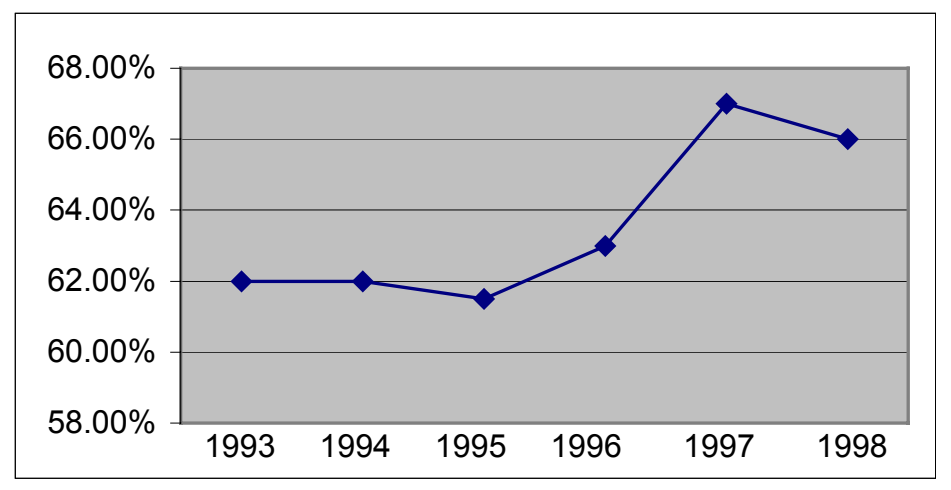

Source: BLS, Current Population Survey

Since education is increasing among technicians, we asked transit agencies to identify how many of their technicians were ASE certified. According to the results from the recruitment and retention survey, only $16 \%$ (336) of the technicians employed by the agencies surveyed hold an ASE certification while 51\% $(1,102)$ of the technicians in 
those agencies do not. The response rate for this question was $89 \%$, which may have contributed to considerably smaller numbers. The National Institute for Automotive Service Excellence (ASE) has 438,000 registered technicians with certifications. While there are 18 different types of ASE certifications, the areas that could apply to the transit maintenance technicians are significantly low.

\section{INNOVATIVE STRATEGIES}

Public transit agencies are faced with many employment issues, specifically related to maintenance technicians. As we have seen in the previous sections, there are many conditions that are affecting transit agencies' ability to retain and recruit maintenance technicians, including low unemployment, a demographic shift, an aging workforce, social and educational changes, and an ongoing technological revolution. Faced with these circumstances, public transit agencies will have to counter these by employing innovative mechanisms to retain and recruit new technicians. In this section, we will identify recruiting and retention strategies that have been implemented in a number of the nation's transit agencies.

\section{Continuing Education and Professional Development}

As previously discussed, keeping technicians up-to-date on their education will benefit technicians and employers. Many agencies have already discovered the importance of continuing education and professional development because it can help in the retention and recruitment of technicians. Technicians will enjoy challenging their minds and improving their skill sets, while the transit agency will enjoy will decreased repair times and mistakes.

Historically, mechanics were trained on the job or by a mentor. Today, however most employers recommend the attainment of a formal engine-training program in addition to a high school degree. Completion of such programs can produce certifications and even 
associate degrees. ${ }^{4}$ In addition, transit agencies are actively working to keep their existing workforce educated and challenged. Transit employers are sending experienced technicians to special training classes, conducted by manufacturers and vendors, where they learn the latest technology and repair techniques. Programs that train, satisfy, mentor and facilitate advancement will have to become the standard if the industry is to develop the necessary talent to remain competitive in this highly competitive field.

Table 1-5 shows some of the additional training and professional development opportunities offered by transit agencies. The most common answers were "on-site training" and "vendor training." Tuition reimbursement and off-site training were two answers that were also common.

Several agencies indicated that they utilized outside source training from organizations such as ASE. Since ASE is a nationally recognized certification program, technicians can use what they have learned internally as well as externally.

Professional development training is another important type of training. This type of training allows individuals to apply what they have learned both within their place of business as well as throughout their life. Opportunities like supervisory, management, career and leadership training are offered to transit maintenance technicians throughout the United States by various transit organizations. (Table 1-5)

While it is important to offer educational and professional development opportunities to employees, it is also critical for transit agencies to create and develop additional programs that will help in the recruitment and retention of the new generation of service technicians.

\footnotetext{
${ }^{4}$ Occupational Outlook Handbook, US Department of Labor, Bureau of Labor Statistics. 2000.
} 
Table 1-5

Training and Professional Development Opportunities

\begin{tabular}{|l|c|}
\hline \multicolumn{1}{|c|}{ Response } & $\begin{array}{c}\text { \# of } \\
\text { Responses }\end{array}$ \\
\hline On-Site Training & 23 \\
\hline Vendor Training & 23 \\
\hline Tuition Reimbursement & 12 \\
\hline Off-Site Training & 11 \\
\hline OEM Training & 6 \\
\hline Certifications/College Courses & 4 \\
\hline Paid ASE Training & 4 \\
\hline Career \& Leadership Dev. Training & 3 \\
\hline Maintenance Training & 3 \\
\hline Promotion Upon Completion of & 2 \\
\hline Courses/Training & 2 \\
\hline CUTR Training & 2 \\
\hline FTA Training & 2 \\
\hline Training Upon Procurement of New Buses & 2 \\
\hline Forty Hours of Training Per Year & 2 \\
\hline Engine \& Transmission Training & 2 \\
\hline Supervisory/Management Training & 2 \\
\hline First Aid/CPR & 1 \\
\hline FDOT Classes & 1 \\
\hline Training Video Cassettes & 1 \\
\hline Driving Training & 1 \\
\hline Manufacturer's Technical Support & 1 \\
\hline OSHA \& EPA Training & 1 \\
\hline Library for Self-Motivated Study & 1 \\
\hline Computer Training & 1 \\
\hline Free Tuition For Degree & 1 \\
\hline Service Schools 2-3 Per Month & 1 \\
\hline Still in Development & 1 \\
\hline Associate of Arts Degree from Local \\
Community College & 1 \\
\hline Nashville Auto Diesel & 1 \\
\hline Universal Technical Institute & 1 \\
\hline Equipment Safety Training & 1 \\
\hline Apprenticeship Program & 1 \\
\hline
\end{tabular}

Source: National Transit Maintenance Technicians Recruitment and Retention Survey, 2001. Center for Urban Transportation Research, University of South Florida, Tampa, Florida 


\section{Recruiting Strategies}

Although the future promises to be filled with challenges in regards to bringing new hires into the transit industry, the opportunity exists now to focus programs in the direction they need to be oriented. Maintenance managers today, in concert with their personnel departments, need to grasp this opportunity and lend their time, energy and knowledge to develop programs specifically designed to train, inform and satisfy. Several transit agencies nationally have already recognized the need for "directional intervention," with positive results.

CUTR staff performed both telephone, written surveys as well as utilized the Internet to gather data relating to strategies used by agencies that affect employee satisfaction and turnover. In one such survey it was noted that, after successful negotiations with their union, San Diego Transit developed a training program that ties promotions to competency instead of seniority ${ }^{5}$. The benefits of a performance based training program impact both current and prospective employees. Current employees see an avenue for advancement that is directly related to their ability and desire to do better. In the technical trades, seniority based advancement has always been a point of contention. This program paves an avenue towards eliminating the animosity sometimes kindled by the seniority based progression module. Additionally, the hiring manager now has the ability to offer a projected path of promotion to prospective employees, rather than the stark truth of advancement when a senior employee "leaves or dies".

Generally, an agency's inability to recruit and retain experienced technicians drives them to become innovative. In recognizing these difficulties, Metra Rail in Chicago has developed an apprenticeship program that utilizes an On-The-Job Training (OJT) approach. They created their program from the ground up, utilizing the latest methods in training and computer assisted record keeping. A detailed task analysis and objectives

\footnotetext{
${ }^{5}$ National Transit Institute, http://www.ntionline.com
} 
list is then created that encompasses all areas of a particular job. The agency then uses mentors, comprised of existing journeyman employees, to help train and track an apprentice's progress. These mentors have been trained in adult learning principals and eagerly create a "training culture." This involvement by existing personnel in the training cycle discourages the practice of using apprentices to do the "grunt labor" that abounds in most shops. Completed tasks must be annotated as such by a mentor, which increases communication and commitment by everyone involved in the process. This program allows Metra Rail to attract quality recruits with the promise of a structured training environment culminating in a work ready employee. This approach also trains existing staff on new technologies, enabling them to keep current while maximizing vehicle availability. Enrollment has more than doubled in a two-year period, leading to significant increases in productivity and quality. ${ }^{6}$

Understanding the human element has become essential to attracting new technicians into the transit workplace. VIA Metropolitan Transit of San Antonio, Texas has embarked on a mission to introduce the belief that employees are an agency's most valuable resource. Taking a holistic approach, VIA's Human Resource Department not only deals with employment and training, it also oversees the company's child development center. ${ }^{7}$ Providing services that reflect the realities of the workplace demonstrates concern for their employees in addition to reducing worker anxiety. Additionally, the department has opened management development and customer service training modules to all employees on a space available basis. Creating a training center that allows all employees to be trained on topics not related to their current job has been an attractive tool that maintains an environment worthy of an employee's commitment. The practice of bringing an employee into the "fold", and creating programs for both the employee and the employee's family, certainly contributes to an employee's decision to stay or leave the company. Promulgating the philosophy that your organization puts a premium on workplace values demonstrates a deep commitment to job satisfaction. To an employee, possessing the skills, knowledge and abilities (SKAs) without the potential for

\footnotetext{
${ }^{6}$ National Transit Institute, http://www.ntionline.com

${ }^{7}$ National Transit Institute, http://www.ntionline.com
} 
advancement fosters frustration and contempt. Programs such as these promise to help alleviate these concerns.

Table 1-6 lists some of the most common ways that transit agencies are recruiting technicians. They range from proactive recruitment techniques, like advertising in local newspapers, to more reactive recruiting such as taking walk in applicants. The most common method for recruiting technicians was through newspaper advertisements. The second most common way to recruit technicians was by word of mouth.

Some transit agencies are using more creative media to advertise job positions like the Internet and radio. These modes reach a large regional area and are typically inexpensive. Additionally, several agencies are attending career fairs and coordinating with technical schools. These recruitment techniques engage relationships with young future technicians and foster communications with potential employees.

One recruitment method that many private sector agencies use to help recruit technicians is to establish a degree program with local technical institutes and colleges. Many private sector businesses foster the creation of comprehensive degree programs with local community colleges. These programs offer students/technicians an opportunity to earn a degree as well as learn on-the job training for college credit. These types of programs, like the Ford Asset Program, have offered many Ford dealerships a good candidate pool of knowledgeable technicians. 
Table 1-6

\section{Recruitment Techniques}

\begin{tabular}{|l|c|}
\hline \multicolumn{1}{|c|}{ Responses } & $\begin{array}{c}\text { Number of } \\
\text { Responses }\end{array}$ \\
\hline Newspaper Advertisements & 48 \\
\hline Word of Mouth & 22 \\
\hline Interviews/Advertisements at Technical Schools & 15 \\
\hline Internet & 8 \\
\hline Internal Job Postings & 7 \\
\hline Career Fairs & 5 \\
\hline Trade Publication Advertisements & 4 \\
\hline City/County/State Job Announcements & 4 \\
\hline Employee Referrals & 4 \\
\hline No Response to Question 11 & 3 \\
\hline Agency Reputation & 2 \\
\hline Internal Promotions & 2 \\
\hline Community Outreach & 2 \\
\hline Job Service & 2 \\
\hline Applications & 2 \\
\hline Union Referrals & 1 \\
\hline In-House Training & 1 \\
\hline Car Shows & 1 \\
\hline Radio Advertisements & 1 \\
\hline MESA Postings & 1 \\
\hline Walk-In Applicants & 1 \\
\hline Mailing List Announcements & 1 \\
\hline Interviews & 1 \\
\hline One to two types of tests & 1 \\
\hline Employment Agencies & 1 \\
\hline Don't Need To & \\
\hline
\end{tabular}

Source: National Transit Maintenance Technicians Recruitment and Retention Survey, 2001. Center for Urban Transportation Research, University of South Florida, Tampa, Florida 


\section{Retention}

Transit organizations are starting to realize that if they are to obtain and retain quality technicians, with the organic ability to acquire the skills necessary for future technologies. The actual length of employment varies from agency to agency, however Figure 1-6 graphically shows the average length of employment of a technician by level. According to the submitted data, Level 1 technicians, who receive the highest pay, are employed for an average of 12.66 years (93\% response rate), level 2 for an average of 9.5 years ( $73 \%$ response rate), level 3 for an average of 5.43 years ( $48 \%$ response rate), and finally level 4 for an average of 3.72 years ( $25 \%$ response rate).

Figure 1-6

\section{Length of Employment}

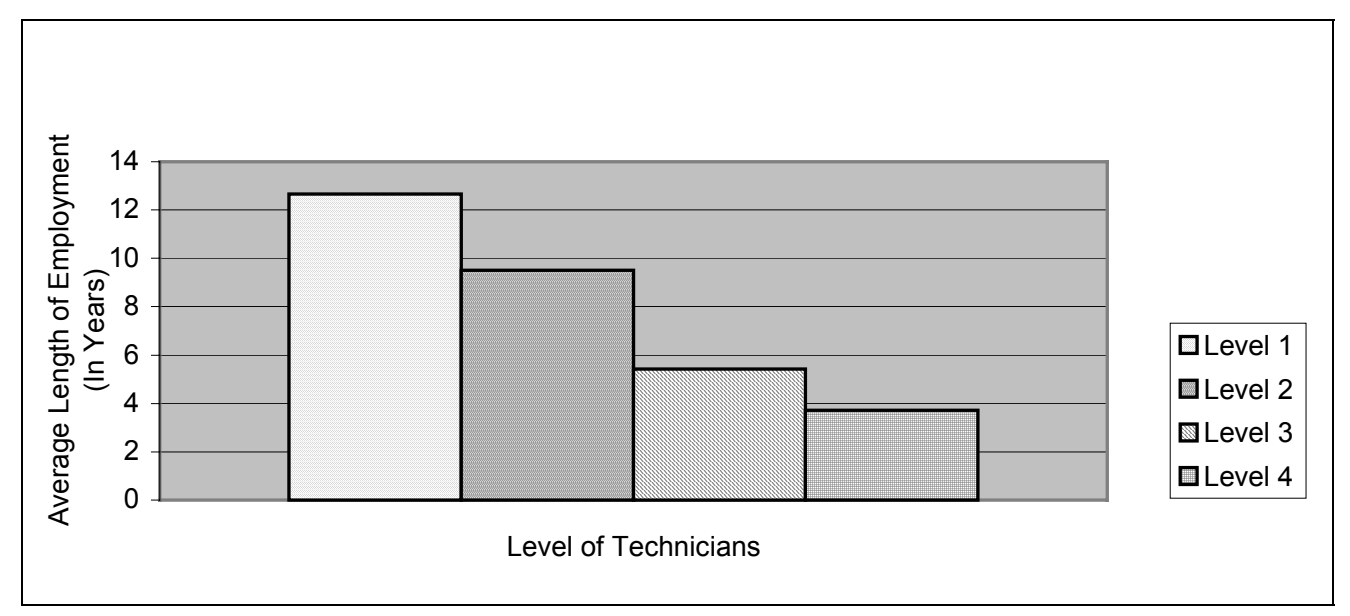

Source: National Transit Maintenance Technicians Recruitment and Retention Survey, 2001. Center for Urban Transportation Research, University of South Florida, Tampa, Florida

With such low averages in the length of employment, agencies must offer more than the usual compensation packages. There are some pioneering ways to increase take-home pay that transit systems have been able to implement. One such example promotes the use of current Department of Treasury regulations. Profit Systems, Inc. (PSI) has developed a plan that allows technicians to get monthly tool reimbursement checks, as 
opposed to an annual one-time payment. This allows a portion of the employee's monthly gross income to be tax free, resulting in a higher take home pay while depreciating the expense of tool purchases. The technician receives two checks per pay cycle, with one of them being tax-exempt. Technicians typically own over $\$ 10,000$ worth of tools and with the constant increase in technology this figure will only become larger. The tool reimbursement plan promises to be both far-reaching and long lasting for those transit agencies willing to explore new horizons.

Another incentive that seems to be prevalent nationwide is the certification bonus. Several agencies that were surveyed offer a cash incentive for those technicians who become ASE certified. In most cases, the technician may receive up to $\$ 150.00$ for each ASE certification held. Tuition reimbursements are also being offered. The benefits for both the technician and the agency are obvious. Less obvious, however, is the everwidening chasm between new technology and the transit industry's ability to train and test on it. Although ASE does a good job of administering automotive and technical tests, a true examination that represents transit specific technology is currently nonexistent. Traditionally, agencies have relied on in-house training supplemented by vendor instruction for most of their training needs. Increasingly, organizations are starting to recognize the need for specific training and are take positive steps to create new methodologies and practices.

In Tampa, Florida, the Hillsborough Area Regional Transit system (HARTline) is in the process of developing a Maintenance Training Center. In conjunction with the Florida Department of Transportation (FDOT) and the Florida Maintenance Training Program (FMTP), located at the Center for Urban Transportation Research at the University of South Florida, the center will house training simulators, computer-based training, and hands-on courses. Currently, HARTline has developed an intra-net system, where bus and component manuals are available in electronic form to all technicians on the maintenance shop floor. Technicians simply go to one of 8 computer terminals on the shop floor, choose the right manual, and then "flip" through it right on the screen. 
Some agencies are using overtime opportunities as a method of retaining employees. Voluntary overtime allows employees the flexibility to earn additional income. Table 17 lists some of the overtime opportunities offered throughout the US. Many of the responses illustrate a strong willingness on the part of the employer to increase overtime opportunities and employees to accept those opportunities. Most respondents offered overtime opportunities as "coverage for vacationing or sick" colleagues. The second most common answer was "not offering any overtime opportunities." The third most common response was that overtime opportunities were directly proportional to workload. 
Table 1-7

\section{Opportunities for overtime}

\begin{tabular}{|c|c|}
\hline Responses & $\begin{array}{l}\text { Number of } \\
\text { Responses }\end{array}$ \\
\hline No response & 14 \\
\hline Only for emergency service & 1 \\
\hline Coverage for vacations/illness & 10 \\
\hline Holidays and off-days worked & 2 \\
\hline Over 40 hours in one week or 8 hours in one day & 2 \\
\hline $11 / 2$ time - work first day off/ double time & 1 \\
\hline Overtime pay is available & 1 \\
\hline Overtime is worked on regular basis & 1 \\
\hline No opportunities for Overtime & 6 \\
\hline As needed, 2-3 hours per tech per week & 3 \\
\hline Special projects & 3 \\
\hline Man power shortages & 2 \\
\hline Repair/PM of buses & 1 \\
\hline Overtime voluntary when the workload is out & 1 \\
\hline Special events requiring maintenance support & 1 \\
\hline Scheduled overtime - Saturday shifts & 2 \\
\hline As required overtime - unscheduled & 1 \\
\hline Personnel shortage & 1 \\
\hline Work load & 5 \\
\hline Overtime is restricted monthly & 2 \\
\hline Overtime available throughout the year & 1 \\
\hline Time and a half or comp@1 and a half pay & 1 \\
\hline Overtime pay by seniority or specialty & 2 \\
\hline Training & 1 \\
\hline Workers compensation & 1 \\
\hline Overtime as needed & 1 \\
\hline Snowstorm/special events & 1 \\
\hline Fleet Campaign & 2 \\
\hline Overtime is available on an irregular basis & 1 \\
\hline Unlimited overtime & 2 \\
\hline $6^{\text {th }}$ day overtime & 1 \\
\hline $7^{\text {th }}$ day double time & 1 \\
\hline Additional hours in shop & 1 \\
\hline Weekend driving & 1 \\
\hline Snowplowing & 2 \\
\hline Overtime & 1 \\
\hline Sporadic opportunity depending upon budget & 1 \\
\hline Snow and ice emergencies & 1 \\
\hline On call responses & 2 \\
\hline Shift differential & 1 \\
\hline Overtime through regular duties & 1 \\
\hline Limited overtime available & 1 \\
\hline Unscheduled overtime & 1 \\
\hline
\end{tabular}

Source: National Transit Maintenance Technicians Recruitment and Retention Survey, 2001. Center for Urban Transportation Research, University of South Florida, Tampa, Florida 
Table 1-8 shows some of the most common ways in which transit agencies retain their maintenance technicians. Benefits and Pay were the two most common answers to this question followed by a good working environment.

It was clear from the responses that while some agencies were not able to compensate their technicians through benefit or pay, they temper this by offering job security, paid training and opportunities for advancement.

Table 1-8

Techniques For Retaining Technicians

\begin{tabular}{|l|c|}
\hline \multicolumn{1}{|c|}{ Responses } & \# of Responses \\
\hline Benefits & 34 \\
\hline Pay & 34 \\
\hline Work Environment/ Conditions & 18 \\
\hline Job Security & 9 \\
\hline Paid Training & 7 \\
\hline Opportunity for advancement & 7 \\
\hline No response & 5 \\
\hline ASE Bonus & 5 \\
\hline Flexible Work Hours & 3 \\
\hline Respect & 3 \\
\hline Awards & 2 \\
\hline Tool Allowance & 2 \\
\hline Celebrate Occasions & 1 \\
\hline Overtime Opportunity & 1 \\
\hline Company Reputation & 1 \\
\hline Compressed Work Week & 1 \\
\hline
\end{tabular}

Source: National Transit Maintenance Technicians Recruitment and Retention Survey, 2001. Center for Urban Transportation Research, University of South Florida, Tampa, Florida 


\section{CONCLUSION}

As mentioned in the beginning, answering the question, "Where are the future transit maintenance technicians coming from?" is not easy. There are many variables that affect this occupation. It is clear that transit agencies will have some major issues to contend with over the next several years. From a strong economy, to low unemployment rates, a technological revolution, and large portions of our employee retiring, the ability of transit agencies to recruit and retain technicians will become increasingly more difficult.

Our society as a whole is changing at a rapid pace. As the way of the world changes, we must alter our thinking and redirect our efforts to address new issues. The world in which transit maintenance technicians live today is very different than in years past. Transit agencies need to identify what is important to today's technicians and offer programs and incentives to match these needs. If transit agencies continue to recruit and retain technicians in the same manner they have in the past, they could experience a continual decrease in their employment numbers.

As discussed previously, many transit agencies are trying to counter future employment issues by investing in creative recruitment and retention programs today. By understanding the transit maintenance technician marketplace as a whole, they can prepare for the future. 
APPENDIX A 


\section{APPENDIX A}

Names and Address of Respondents

\begin{tabular}{|c|c|c|}
\hline Agency Name & City & State \\
\hline First Transit & Blum & Alabama \\
\hline City of Scottsdale & Scottsdale & Arizona \\
\hline Phoenix Transit & Phoenix & Arizona \\
\hline Golden Gate Transit & San Rafael & California \\
\hline Orange County Transportation Authority & Orange & California \\
\hline Fresno Area Express & Fresno & California \\
\hline Riverside Transit Agency & Riverside & California \\
\hline San Mateo County Transit District & San Carlos & California \\
\hline Omnitrans & San Bernardino & California \\
\hline Culver City Municipal Bus Lines & Culver City & California \\
\hline Long Beach Transit & Long Beach & California \\
\hline Alameda-Contra Costa Transit District & Oakland & California \\
\hline Greater Bridgeport Transit Authority & Bridgeport & Connecticut \\
\hline University of Connecticut Motorpool & Storrs & Connecticut \\
\hline Central Florida Regional Transportation Authority & Orlando & Florida \\
\hline Hillsborough Area Regional Transit & Tampa & Florida \\
\hline Broward County - Division of Mass Transit & Pompano Beach & Florida \\
\hline Lee County Transit & Ft. Myers & Florida \\
\hline City of Tallahassee - TALTRAN & Tallahassee & Florida \\
\hline Sarasota County, Transit/Fleet & Sarasota & Florida \\
\hline Manatee County Fleet Services & Bradenton & Florida \\
\hline Athens Transit System & Athens & Georgia \\
\hline $\begin{array}{l}\text { Department of Transportation Services } \\
\text { C \& C of Honolulu }\end{array}$ & Honolulu & Hawaii \\
\hline Des Moines Metro Transit Authority & Des Moines & lowa \\
\hline lowa City Transit & lowa City & lowa \\
\hline South Bend Public Transportation Corp. & South Bend & Indiana \\
\hline Muncie Indiana Transit System & Muncie & Indiana \\
\hline City Bus & LaFayette & Indiana \\
\hline Topeka Transit & Topeka & Kansas \\
\hline Transit Authority of River City & Louisville & Kentucky \\
\hline LexTran & Lexington & Kentucky \\
\hline Louisiana Transit & Metairie & Louisiana \\
\hline UMASS Transit Service & Amherst & Massachusetts \\
\hline Division of Fleet Management Services & Rockville & Maryland \\
\hline Lake Erie Transit & Monroe & Michigan \\
\hline Interurban Transit Partnership & Grand Rapids & Michigan \\
\hline Blue Water Area Transit & Port Huron & Michigan \\
\hline Kalamazoo Metro Transit & Kalamazoo & Michigan \\
\hline Capital Area Transit Authority & Lansing & Michigan \\
\hline $\begin{array}{l}\text { Laidlaw Transit Services Inc. - Minnesota Valley } \\
\text { Transit Authority }\end{array}$ & Burnsville & Minnesota \\
\hline $\begin{array}{l}\text { Schmitty \& Son Buses Minnesota Valley Transit } \\
\text { Authority }\end{array}$ & Zakeville & Minnesota \\
\hline Duluth Transit Authority & Duluth & Minnesota \\
\hline Mountain Line & Missoula & Montana \\
\hline
\end{tabular}


APPENDIX A (Continued)

Names and Address of Respondents

\begin{tabular}{|l|c|c|}
\hline \multicolumn{1}{|c|}{ Agency Name } & City & State \\
\hline GTA & Greensboro & North Carolina \\
\hline Capital District Transportation Authority & Albany & New York \\
\hline Community Action Committee of Pike County & Piketon & Ohio \\
\hline Lane Transit District & Eugene & Oregon \\
\hline $\begin{array}{l}\text { TRI-MET (Tri-County Metropolitan Transportation } \\
\text { District of Oregon }\end{array}$ & Portland & \\
\hline Area Transportation Authority & & Pennsylvania \\
\hline Cambria County Transit Authority & Johnsonburg & Pennsylvania \\
\hline Rabbit Transit & Johnstown & Pennsylvania \\
\hline Transit Management of Spartanburg, Inc. & York & South Carolina \\
\hline Sioux Falls Transit & Spartanburg & South Dakota \\
\hline Capital Metropolitan Transportation Authority & Sioux Falls & Texas \\
\hline Citibus & Austin & Texas \\
\hline Waco Transit System & Lubbock & Texas \\
\hline Park City Municipal Corporation & Waco & Utah \\
\hline Link Transit & Park City & Washington \\
\hline Clallam Transit System & Wenatcher & Washington \\
\hline Skagit Transit & Port Angeles & Washington \\
\hline C-TRAN & Burlington & Washington \\
\hline Intercity Transit & Vancouver & Washington \\
\hline Waukesha Metro Transit & Olympia & Wisconsin \\
\hline Milwaukee Transport Services, Inc. & Waukesha & Wisconsin \\
\hline La Crosse Municipal Transit Utility & Milwaukee & Wisconsin \\
\hline
\end{tabular}


APPENDIX B 


\section{RESOURCES}

Bureau of Labor Statistics, Occupational Outlook Handbook, US Department of Labor, 2000.

Department of Labor, Futurework- Trends and Challenges for Work of to $21^{\text {st }}$ Century. www.dol.gov/dol/asp/public/futurework/report.htm

Jennifer Cheeseman Day, Population Projections of the United States by Age, Sex, Race and Hispanic Origin: 1995 to 2050, Current Population Reports, Series P-25-1130

(Bureau of the Census, 1996)

Arlene Dohm, Gauging the Labor Force Effects of Retiring Baby-Boomers, Monthly Labor Review, July 2000

Patrick J. Purcell, Older Workers; Employment and Retirement Trends, Monthly Labor Review, October 2000.

National Institute for Automotive Service Excellence, 13505 Dulles Technology Drive, Suite 2 $\cdot$ Herndon, Virginia 20171-3421

National Transit Institute, Rutgers, The State University of New Jersey, New Brunswick, New Jersey. 08901-2163. http://www.ntionline.com

Occupations with the greatest percentage of workers aged 45 and older permanently leaving the occupation, 1998-2008 Bureau of Labor Statistics, Arlene Dohm, Monthly Labor Review, July 2000. "Gauging the labor force effect of retiring baby boomers."

U.S. Population aged 25 and older by age and sex, 2000, $2010:$ Jennifer Cheeseman Day, Population Projections of the United States by Age, Sex, Race and Hispanic Origin: 1995 to 2050, Current Population Reports, Series P-25-1130 (Bureau of the Census, 1996)

D.J. Periana, Service Director, Reeves Import Motorcars, Tampa, Fl.

Robert Russell, Automotive Instructor, Brewster Technical College, Tampa, Fl.

Art Shor, Automotive Instructor, First Coast Technical Institute, St. Augustine, Fl.

Robert Westbrook, Florida Department of Transportation, Tallahassee, Fl.

National Institute for Automotive Service Excellence 2001, National Institute for Automotive Service Excellence, Herndon, Virginia

Bureau of Labor Statistics, 2000. Number of Diesel and Automotive Mechanics, Department of Labor Occupational Outlook Handbook, US Department of Labor. 
